\title{
Pemilihan Makanan Pendamping ASI Pada Batita Dengan Menerapkan Metode TOPSIS
}

\author{
Eka Ridhawati ${ }^{1}$, Leonita Julianti ${ }^{2}$ \\ ${ }^{1}$ Program Studi Sistem Informasi STMIK Pringsewu \\ ${ }^{2}$ Program Studi Sistem Informasi STMIK Pringsewu \\ ${ }^{1}$ ekaridhawati@gmail.com \\ ${ }^{2}$ juliantileonita020@gmail.com
}

\begin{abstract}
Infants aged six to twenty-four months, starting with complementary feeding of milk (MPASI). MPASI should be sufficient for infants, to meet the nutritional needs of infant growth, with attention to the fulfillment of nutritional needs, nutrition is one factor that must be considered. A mother will prepare food for her baby, taking into account the fulfillment of nutrition, so it will be very efficient in terms of time and energy. Therefore, this study proposes the construction of a system to recommend complementary foods of breast milk. By considering the baby's nutritional needs for optimal infant development, this research uses technique for order preference method by similarity to ideal solution (TOPSIS). Stages performed in this research is data collection, analysis of application methods, implementation, and testing. Determining criteria include brain development, body resistance, optimal physical growth and bone development that takes several alternatives: team rice, vegetable puree, fruit juice, and baby cereal. In this study, the best choice in providing complementary feeding of milk is using an alternative cereal with the yield of 0.619. So from this study concluded that the best alternative is Cereal, with the amount of time to eat according to the baby's age with attention to nutrition to the food ingredients used.
\end{abstract}

Keywords: Complementary Feedi; Baby Nutrition; TOPSIS

\begin{abstract}
Abstrak
Bayi usia enam sampai dengan dua puluh empat bulan, mulainya diberikan makanan pendamping ASI (MPASI). MPASI harus bersifat mencukupi untuk bayi, guna memenuhi kebutuhan nutrisi pertumbuhan bayi, dengan memperhatikan pemenuhan kebutuhan nutrisi, gizi merupakan salah satu faktor yang wajib diperhatikan. Seorang ibu akan mempersiapkan makanan untuk bayinya, dengan mempertimbangkan pemenuhan gizi, sehingga dirasa akan sangat efisien dari segi waktu dan tenaga. Untuk itu, penelitian ini mengusulkan dibangunnya sebuah system untuk merekomendasikan makanan pendamping ASI. Dengan mempertimbangkan kebutuhan gizi bayi agar perkembangan bayi lebih optimal, penelitian ini menggunakan metode technique for order preference by similarity to ideal solution (TOPSIS). Tahapan yang dilakukan dalam penelitian ini adalah pengumpulan data, analisa penerapan metode, implementasi, dan pengujian. Menentukan kriteria antara lain perkembangan otak, ketahanan tubuh, pertumbuhan fisik yang optimal dan perkembangan tulang yang mengambil beberapa alternative yaitu nasi tim, pure sayuran, jus buah, dan sereal bayi. Dalam penelitian ini, menghasilkan pilihan terbaik dalam memberikan makanan pendamping ASI yaitu menggunakan alternatif Sereal dengan perolehan hasil sebesar 0,619. Sehingga dari penelitian ini menyimpulkan bahwa alternatif terbaik adalah Sereal, dengan jumlah waktu makan sesuai usia bayi dengan memperhatikan nutrisi terhadap bahan makanan yang digunakan.
\end{abstract}

Kata Kunci : Makanan Pendamping ASI; Gizi Bayi; TOPSIS 


\section{PENDAHULUAN}

\subsection{Latar Belakang Masalah}

Decision Support Systems (DSS) adalah bagian dari sistem informasi berbasis komputer yang dipakai untuk mendukung pengambilan keputusan dalam suatu organisasi atau perusahaan. Terdapat beberapa tahapan dalam sistem pendukung keputusan yaitu mendefinisikan masalah, pengumpulan data yang relevan dan sesuai, pengolahan data menjadi informasi. Masalah yang dihadapi adalah pemilihan menu makanan pendamping ASI yang baik dan sesuai kebutuhan batita yang mendorong untuk diadakan sebuah sistem pengambilan keputusan (DSS) sehingga dalam pengambilan keputusan atau penentuannya dapat lebih efektif

Makanan pendamping ASI (MPASI) perlu diberikan ketika bayi berusia 6 bulan ke atas. ASI memang menjadi makan pokok bagi bayi, namun ketika usianya sudah beranjak 6 bulan ke atas, bayi sudah mulai memerlukan nutrisi lain yang tidak hanya berasal dari ASI. Nutrisi itulah yang didapatkan dari makanan pendamping asi MPASI ini. Selain sebagai tambahan nutrisi pemberian MPASI ini bisa melatih bayi untuk mulai mencerna makanan selain ASI. Pemberian MPASI ini pun tidak boleh sembarangan. Pemberian produk makanan bubur atau mengolah bubur sendiri pun harus ada pertimbangannya, agar MPASI yang diberikan bukan malah merugikan si bayi. Karena pemberian MPASI yang salah dapat menimbulkan beberapa resiko bagi bayi.

World Healt Organization (WHO) memperkirakan 2 dari 5 anak tidak tumbuh dengan baik pada negaranegara berpenghasilan rendah(WHO 2014). Oleh karena itulah maka pemberian MPASI harus bersifat mencukupi, yang artinya makanan tersebut harus diberikan dalam jumlah, frekuensi, konsistensi, dan menggunakan bermacam makanan untuk memenuhi kebutuhan nutrisi bagi pertumbuhan anakdengan masih memperhatikan keberlangsungan pemberian ASI (WHO 2014).

Penelitian terdahulu yang terkait sistem rekomendasi resep makanan yang dilakukan oleh Mikami (2014) memperhatikan beberapa faktor dalam menentukan rekomendasi resep makanan yaitu keseimbangan kandungan protein, lemak dan karbohidrat dalam setiap bahan makanan.

TOPSIS dipilih karena dapat mengevaluasi solusi terbaik dengan nilai tertinggi dari indeks persamaan dan cocok digunakan untuk merekomendasikan resep makanan. Metode TOPSIS untuk menentukan pilihan atau alternatif yang paling mendekati kebutuhan. Sebelum itu, dilakukan filtering terlebih dahulu berdasar masukan dari pengguna terkait gizi yang dibutuhkan bayi serta kriteria yang sang bayi butuhkan dalam perkembangannya. Dari kombinasi yang dibuat tersebut akan ditentukan mana yang paling mendekati kebutuhan berdasar kandungan protein, lemak dan karbohidrat.

Dalam pelaksanaannya penentuan jenis makanan,dan kandungan gizi yang dibutuhkan oleh bayi yang sesuai maka dipilih beberapa alternatif yang digunakan dalam menu makanan pendamping ASI, setiap alternatif memiliki masing-masing bobot untuk menentukan makanan terbaik.

\section{KERANGKA TEORI}

\subsection{Decision Support System (DSS)}

Menurut para ahli definisi dari DSS adalah sebagai berikut : Menurut Al-Hamdany (2003: 519), DSS adalah sistem informasi interaktif yang mendukung proses pembuatan keputusan melalui presentasi informasi yang dirancang secara spesifik untuk pendekatan penyelesaian masalah dan kebutuhan-kebutuhan aplikasi para pembuat keputusan, serta tidak membuat keputusan untuk pengguna. 
Sistem pendukung keputusan memiliki karakteristik sebagai berikut:

1. Sistem pendukung keputusan dirancang untukmembantu pengambilan keputusan dalam memecahkan masalah yang bersifat semi terstruktur dengan menambahkan kebijaksanaan manusia dan informasi komputerisasi.

2. Dalam proses pengolahannya, sistem pendukung keputusan mengkombinasikan pengguna model-model analisi dengan teknik pemasukkan data konvesional serta fungsi- fungsi interogasi informasi.

3. Sistem pendukung keputusan, dirancang sedemikian rupa sehingga dapat digunakan atau dioperasikan dengan mudah.

4. Sistem pendukung keputusan dirancang dengan menemukan pada aspek fleksibilitas serta kemampuan beradaptasi yang tinggi.

\subsection{Definisi Makanan Pendamping ASI bagi Batita}

MPASI merupakan makanan bayi kedua yang menyertai pemberian ASI. Makanan pendamping ASI merupakan makanan yang diberikan pada bayi yang telah berusia 6 bulan atau lebih karena ASI tidak lagi memenuhi kebutuhan gizi bayi. Pemberian makanan pendamping ASI harus disesuaikan dengan usia batita. Pemberian makanan pendamping ASI harus bertahap dan bervariasi dari mulai bentuk bubur kental, sari buah, buah segar, makanan lumat, makanan lembek dan akhirnya makanan padat. Makanan pendamping ASI diberikan pada bayi di samping ASI.

Menurut Depkes RI (2006), periode emas dapat diwujudkan apabila pada masa ini bayi dan anak memperoleh asupan gizi yang sesuai untuk tumbuh kembang optimal. Sebaliknya apabila bayi dan anak pada masa ini tidak memperoleh makanan sesuai kebutuhan gizinya, maka periode emas akan berubah menjadi periode kritis yang akan mengganggu tumbuh kembang bayi dan anak, baik pada saat ini maupun masa selanjutnya.

\subsection{Metode Topsis}

Olson (2006) TOPSIS adalah salah satu metode pengambilan keputusan multikriteria yang pertama kali diperkenalkan oleh Yoon dan Hwang tahun 1981. TOPSIS didasarkan pada konsep dimana alternatif yang terpilih atau terbaik tidak hanya mempunyai jarak terdekat dari solusi ideal positif, namun juga memiliki jarak terjauh dari solusi ideal negatif dari sudut pandang geometris dengan menggunakan jarak Euclidean untuk menentukan kedekatan relatif dari suatu alternatif dengan solusi optimal. Solusi ideal positif didefinisikan sebagai jumlah dari seluruh nilai terbaik yang dapat dicapai untuk setiap atribut, sedangkan solusi negatif-ideal terdiri dari seluruh nilai terburuk yang dicapai untuk setiap atribut. Langkah-lahkah metode TOPSIS sebagai berikut :

1. Menghitung hasil pangkat per kriteria ternormalisasi.

$\mathrm{Cx}=A 1^{2}+A 2^{2}+A 3^{2}+A 4^{2}$

2. Menghitung akar hasil pangkat per kriteria

$\mathrm{Cx}=\sqrt{A 1^{2}+A 2^{2}+A 3^{2}+A 4^{2}}$

3. Menentukan data ternormalisasi

Rumus Normalisasi $=$

$\frac{\text { Bobot Kriteria }}{\text { Akar Hasil Pangkat per Kriteria }}$

4. Menentukan data normalisasi terbobot

Normalisasi terbobot $=$ data normalisasi $\mathrm{x}$ bobot kriteria 
5. Menentukan maksimum dan minimum dari data normalisasi terbobot

6. Mencari $d+$ dan $d-$ setiap kriteria

$$
\begin{gathered}
D_{x}+=\sqrt{\begin{array}{c}
\left(d_{x} .1-\max C 1\right)^{2}+ \\
\left(d_{x} .2-\max C 2\right)^{2}+ \\
\left(d_{x} .3-\max C 3\right)^{2}+ \\
\left(d_{x} .4-\max C 4\right)^{2}
\end{array}} \\
D_{x^{-}}=\sqrt{\begin{array}{c}
\left(d_{x} .1-\min C 1\right)^{2}+ \\
\left(d_{x} .2-\min C 2\right)^{2}+ \\
\left(d_{x} .3-\min C 3\right)^{2}+ \\
\left(d_{x} .4-\min C 4\right)^{2}
\end{array}}
\end{gathered}
$$

7. Mencari hasil

$$
V_{x}=\frac{D_{x}-}{\left(D_{x}^{-}\right)+\left(D_{x}+\right)}
$$

Keterangan :

$V_{x}=$ Hasil perhitungan dari $D_{x}$

\section{METODE PENELITIAN}

\subsection{Pengumpulan Data}

Dalam penelitian ini menggunakan metode pengumpulan data antara lain sebagai berikut:

Wawancara adalah teknik pengumpulan data yang dilakukan melalui tatap muka dan tanya jawab langsung antara peneliti dan narasumber. Seiring perkembangan teknologi, metode wawancara dapat pula dilakukan melalui mediamedia tertentu, misalnya telepon, email, atau skype. Wawancara terbagi atas dua kategori, yakni wawancara terstruktur dan tidak terstruktur.

\section{Metode Wawancara}

Wawancara adalah teknik pengumpulan data yang dilakukan melalui tatap muka dan tanya jawab langsung antara peneliti dan narasumber. Seiring perkembangan teknologi, metode wawancara dapat pula dilakukan melalui media-media tertentu, misalnya telepon, email, atau skype. Wawancara terbagi atas dua kategori, yakni wawancara terstruktur dan tidak terstruktur.

a. Wawancara terstruktur

Dalam wawancara terstruktur, peneliti telah mengetahui dengan pasti informasi apa yang hendak digali dari narasumber. Pada kondisi ini, peneliti biasanya sudah membuat daftar pertanyaan secara sistematis. Peneliti juga bisa menggunakan berbagai instrumen penelitian seperti alat bantu recorder, kamera untuk foto, serta instrumen-instrumen lain.

b. Wawancara tidak terstruktur

Wawancara tidak terstruktur adalah wawancara bebas. Peneliti tidak menggunakan pedoman wawancara yang berisi pertanyaan-pertanyaan spesifik, namun hanya memuat poin-poin penting dari masalah yang ingin digali dari responden. 
2. Metode Kepustakaan

Metode Kepustakaan merupakan teknik pengumpulan data dengan cara mempelajari referensi berupa dokumen dan mengumpulkan data guna megetahui kebutuhan yang seharusnya dipenuhi dalam makanan pendamping ASI.

\subsection{Model Perancangan}

Metode pengembangan sistem yang akan digunakan oleh penulis adalah model sekuensial linier(classiclife cycle/waterfall model) sering disebut Model Waterfall. Dalam metode tersebut, terdapat beberapa tahapan, yaitu:

1. Rekayasa dan pemodelan sistem informasi,pada tahapan ini dilakukan pengumpulan kebutuhan pada level sistem, yaitu kebutuhan perangkat keras, perangkat lunak, orang dan basis data.

2. Untuk sistem informasi (perangkat lunak) yang analisis kebutuhan sistem informasi, pada tahap ini dilakukan pengumpulan kebutuhan berupa data input,proses yang terjadi dan output yang diharapkan dengan melakukan wawancara dan observasi.

3. Perancangan (Design)

Pada tahap ini menterjemahkan analisa kebutuhan ke dalam bentuk rancangan sebelum penulisan program yang berupa perancangan antar muka (input dan output), perancangan file-file, atau basis data dan merancang prosedur (algoritma).

4. Pengkodean (Coding)

Hasil rancangan diatas diubah menjadi bentuk yang dimengerti oleh mesin dalam bentuk bahasa pemrograman. Jika rancangannya rinci maka penulisan program dapat dilakukan dengan cepat.

5. Tahap selanjutnya adalah verifikasi, pengembang memeriksa apakah semua yang telah dibuat sesuai atau tidak dengan tujuan awal.

6. Tahap akhir adalah pemeliharaan yang termasuk diantaranya instalasi dan proses perbaikan sistem.

\section{HASIL DAN PEMBAHASAN}

\subsection{Perancangan Sistem}

Dalam penyeleksian penentuan menu makanan yang baik dalam pemenuhan gizi bagi batita yang sesuai dengan kriteria yang diinginkan ini akan menggunakan metode Technique for Others Reference by Similarity to Ideal Solution (TOPSIS) diperlukan kriteria-kriteria dan bobot untuk melakukan perhitungannya sehingga akan didapat alternatif terbaik.

\subsection{Bobot Kriteria}

Dalam metode penelitian ini ada bobot dan kriteria yang dibutuhkan untuk menentukan jenis makanan pendamping ASI yang baik dan memenuhi kebutuhan batita. Adapun kriterianya adalah:

$\mathrm{C} 1=$ Perkembangan Otak,

$\mathrm{C} 2=$ Ketahanan Tubuh,

C3=Pertumbuhan Fisik yang Optimal,

C4=Perkembangan Tulang.

Dari masing-masing kriteria tersebut,tingkat kepentingan atau bobot kriteria setiap kriteria dinilai dengan 1 sampai 5, yaitu: 

a. Tidak Penting (TP) $=1$
b. Kurang Penting (KP) $=2$
c. $\operatorname{Cukup}(\mathrm{C}) \quad=3$
d. Penting $(\mathrm{P}) \quad=4$
e. Sangat Penting (SP) $=5$

Contoh kasus:

Dari banyaknya jenis makanan atau yang akan dicantumkan, diambil 4 sampel makanan sebagai contoh untuk penerapan metode TOPSIS dalam pemilihan makanan pendamping ASI yang memenuhi kebutuhan batita. Agar alternatif yang dihasilkan nanti benar-benar sesuai dengan keinginan ibu dan kebutuhan batita. Dipilih 4 jenis makanan sebagai alternatif pilihan adalah sebagai berikut:

A1 = Tim,

A2 = Pure Sayuran,

A3 = Jus Buah,

A4 $=$ Sereal.

Tabel 1. Data Alternatif

\begin{tabular}{ccccc}
\hline & C1 & C2 & C3 & C4 \\
\hline A1 & Zat besi & Vit.A,B & - & - \\
A2 & Zat besi & Vit.A,B,C & - & - \\
A3 & - & Vit.C & Omega 3 & - \\
A4 & - & Vit.E & Vit.D \& Kalsium & Vit.D \& Kalsium \\
\hline
\end{tabular}

Tabel 2.Tabel Bobot Kriteria

\begin{tabular}{cl}
\hline Kriteria & Bobot Kriteria \\
\hline Perkembangan otak & 5 \\
Ketahanan Tubuh & 4 \\
Pertumbuhan Optimal & 5 \\
Perkembangan Tulang & 4 \\
\hline
\end{tabular}

Tabel 3. Tabel nilai keputusan

\begin{tabular}{lllll}
\hline & C1 & C2 & C3 & C4 \\
\hline A1 & 4 & 3 & 3 & 2 \\
A2 & 5 & 4 & 2 & 3 \\
A3 & 2 & 4 & 4 & 2 \\
A4 & 3 & 3 & 5 & 4 \\
\hline
\end{tabular}

1. Menghitung hasil pangkat per kriteria

$$
\begin{aligned}
& \mathrm{C} 1=\mathbf{4}^{\mathbf{2}}+\mathbf{5}^{\mathbf{2}}+\mathbf{2}^{\mathbf{2}}+\mathbf{3}^{\mathbf{2}}=16+25+4+9=54 \\
& \mathrm{C} 2=\mathbf{3}^{\mathbf{2}}+\mathbf{4}^{\mathbf{2}}+\mathbf{4}^{\mathbf{2}}+\mathbf{3}^{\mathbf{2}}=9+16+9+16=50 \\
& \mathrm{C} 3=\mathbf{3}^{\mathbf{2}}+\mathbf{2}^{\mathbf{2}}+\mathbf{4}^{\mathbf{2}}+\mathbf{5}^{\mathbf{2}}=9+4+16+25=54 \\
& \mathrm{C} 4=\mathbf{2}^{\mathbf{2}}+\mathbf{3}^{\mathbf{2}}+\mathbf{2}^{\mathbf{2}}+\mathbf{4}^{\mathbf{2}}=4+9+4+16=33
\end{aligned}
$$


2. Menghitung akar hasil pangkat per kriteria

$$
\begin{aligned}
& \mathrm{C} 1=\sqrt{\mathbf{5 4}}=7,3485 \\
& \mathrm{C} 2=\sqrt{\mathbf{5 0}}=7,0710 \\
& \mathrm{C} 3=\sqrt{\mathbf{5 4}}=7,3485 \\
& \mathrm{C} 4=\sqrt{\mathbf{3 3}}=5,7446
\end{aligned}
$$

3. Menentukan data ternormalisasi

$$
\text { C1 }
$$

$\mathrm{r} 1.1=\frac{4}{7,3485}=0,5443$

$\mathrm{r} 1 \cdot 2=\frac{5}{7,3485}=0,6804$

$\mathrm{r} 1.3=\frac{2}{7,3485}=0,2721$

$\mathrm{r} 1.4=\frac{4}{7,3485}=0,4082$

\section{C2}

$\mathrm{r} 2 \cdot 1=\frac{3}{7,0710}=0,4242$

$\mathrm{r} 2 \cdot 2=\frac{4}{7,0710}=0,5656$

$\mathrm{r} 2 \cdot 3=\frac{4}{7,0710}=0,4242$

$\mathrm{r} 2.4=\frac{3}{7,0710}=0,5656$

C3

$\mathrm{r} 3 \cdot 1=\frac{3}{7,3485}=0,4082$

$\mathrm{r} 3.2=\frac{2}{7,3485}=0,2721$

$\mathrm{r} 3 \cdot 3=\frac{4}{7,3485}=0,5443$

$\mathrm{r} 3.4=\frac{5}{7,3485}=0,6804$

C4

$\mathrm{r} 4 \cdot 1=\frac{2}{5,7446}=0,3481$

$\mathrm{r} 4 \cdot 2=\frac{3}{5,7446}=0,5222$

$\mathrm{r} 4.3=\frac{2}{5,7446}=0,3481$

$\mathrm{r} 4 \cdot 4=\frac{4}{5,7446}=0,6963$ 
4. Menentukan data normalisasi terbobot

Tabel 4. Tabel data normalisasi terbobot

\begin{tabular}{ccccc}
\hline & $\mathrm{C} 1$ & $\mathrm{C} 2$ & $\mathrm{C} 3$ & $\mathrm{C} 4$ \\
\hline 1 & 2,722 & 1,697 & 2,041 & 1,044 \\
2 & 3,402 & 2,262 & 1,361 & 1,567 \\
3 & 1,361 & 2,262 & 2,722 & 1,044 \\
4 & 2,041 & 1,696 & 3,402 & 2,089 \\
\hline
\end{tabular}

5. Menentukan maksimum dan minimum dari data normalisasi terbobot

Tabel 5. Tabel maksimum dan minimum

\begin{tabular}{ccccc}
\hline & C1 & C2 & C3 & C4 \\
\hline maksimum & 3,402 & 2,262 & 3,402 & 2,089 \\
minimum & 1,361 & 1,698 & 1,361 & 1,044 \\
\hline
\end{tabular}

6. Mencari D+ dan D- setiap kriteria

$$
\begin{aligned}
& \text { a. } \quad D_{1}+=\sqrt{\begin{array}{c}
(2,722-3,402)^{2}+ \\
(1,697-2,262)^{2}+ \\
(2,041-3,402)^{2}+ \\
(1,044-2,089)^{2}
\end{array}} \\
& =\sqrt{3,723}=1,930 \\
& \text { b. } \quad D_{2}+=\sqrt{\begin{array}{c}
(3,402-3,402)^{2}+ \\
(2,262-2,262)^{2}+ \\
(1,361-3,402)^{2}+ \\
(1,567-2,089)^{2}
\end{array}} \\
& =\sqrt{4,890}=2,211
\end{aligned}
$$

c. $\quad D_{3}+=\sqrt{\begin{array}{c}(1,361-3,402)^{2}+ \\ (2,262-2,262)^{2}+ \\ (2,722-3,402)^{2}+ \\ (1,044-2,089)^{2}\end{array}}$

$$
=\sqrt{5,726}=2,393
$$

d. $\quad D_{4}+=\sqrt{\begin{array}{c}(2,041-3,402)^{2}+ \\ (1,696-2,262)^{2}+ \\ (3,402-3,402)^{2}+ \\ (2,089-2,089)^{2}\end{array}}$

$$
=\sqrt{2,173}=1,474
$$

e. $\quad D_{1^{-}}=\sqrt{\begin{array}{c}(2,722-1,361)^{2}+ \\ (1,697-1,697)^{2}+ \\ (2,041-1,361)^{2}+ \\ (1,044-1,044)^{2}\end{array}}$

$$
=\sqrt{2,315}=1,522
$$

f. $\quad D_{2^{-}}=\sqrt{\begin{array}{c}(3,402-1,361)^{2}+ \\ (2,262-1,697)^{2}+ \\ (1,361-1,361)^{2}+ \\ (1,567-1,044)^{2}\end{array}}$

$$
=\sqrt{6,359}=2,522
$$




$$
\begin{aligned}
& \text { g. } \quad D_{3^{-}}=\sqrt{\begin{array}{c}
(1,361-1,361)^{2}+ \\
(2,262-1,697)^{2}+ \\
(2,722-1,361)^{2}+ \\
(1,044-1,044)^{2}
\end{array}} \\
& =\sqrt{2,171}=1,473 \\
& \text { h. } \quad D_{4^{-}}=\sqrt{\begin{array}{c}
(2,041-1,361)^{2}+ \\
(1,697-1,697)^{2}+ \\
(3,402-1,361)^{2}+ \\
(2,089-1,044)^{2}
\end{array}} \\
& =\sqrt{5,722}=2,392
\end{aligned}
$$

7. Mencari hasil

$$
\begin{aligned}
& V_{1}=\frac{1,522}{1,522+1,930}=0,441 \\
& V_{2}=\frac{2,522}{2,522+2,211}=0,533 \\
& V_{3}=\frac{1,473}{1,473+2,393}=0,381 \\
& V_{4}=\frac{2,392}{2,392+1,474}=0,619
\end{aligned}
$$

Hasil perhitungan nilai $V_{x}$ yang lebih besar mengindikasikan merupakan alternatif yang terbaik (Kusumadewi, Hartati, Harjoko, \& Wardoyo, 2006). Hasil perhitungan terbesar ada pada $V_{4}$ yaitu Sereal sehingga Sereal dapat dijadikan pilihan dalam pemilihan makanan pendamping ASI sebagai alternatif terpilih yang terbaik.

\subsection{Implementasi}

Hasil yang didapatkan dari sistem pendukung keputusan Pemilihan menu makanan dengan metode for order preference by similarity to ideal solution (TOPSIS) ini terdiri dari beberapa modul halaman-halaman atau antar muka pemakai.

\section{KESIMPULAN}

1. Penelitian ini telah mendapatkan hasil mendapatkan hasil yang menyatakan bahwa alternatif ke 4 atau Sereal dengan perolehan hasil sebesar 0,619 dengan menggunakan metode TOPSIS.

2. Sistem yang dirancang merupakan sistem pendukung keputusan pemilihan menu makanan pendamping ASI, untuk pengembangan sistem dapat dilakukan dengan merancang Sistem Informasi berbasis website menjadi pengembangan yang tepat agar aplikasi dapat diakses dimana saja dan oleh siapa saja.

3. Dalam pembuatan jurnal atau penelitian mengenai MPASI ini bisa dikembangkan dengan banyak metode lainnya,tidak hanya terpaku dengan metode TOPSIS saja. 


\section{DAFTAR PUSTAKA}

Abdul Chamid, Ahmad. 2016. Penerapan Metode Topsis Untuk Menentukan Prioritas Kondisi Rumah. Kudus. Universitas Muria Kudus.

Fitri Boy, Ahmad, Marsono, Wulandari. 2015. Sistem Pendukung Keputusan Pemiliuhan Menu Makanan pada Penderita Obesitas dengan menggunakan Metode Topsis. Medan . STMIK Triguna Dharma.

Irawan, Andi, Elisabeth Yunaeti Anggraeni. 2017. Sistem Pendukung Keputusan

Penyeleksian Calon Siswa Baru di SMP Negei 1 Banyumas. Pringsewu. STMIK Pringsewu.

Widodo, Retno, A.Khumaidi. 2016. Penggunaan Sistem Penunjang Keputusan Untuk Menentukan Genteng Terbaik Dengan Menggunakan Metode Ahp Pada Desa Kalirejo. Pringsewu. STMIK Pringsewu.

Sihwi, S.Widya, Hestin Mulyasari, Ristu Saptono dan Budianti Wiboworini. 2016. Sistem Rekomendasi Menu Harian Makanan Pendamping Air Susu Ibu (MPASI) Berdasarkan Kebutuhan Kalori Bayi dengan Metode TOPSIS. Surakarta . Universitas Negeri Sebelas Maret. 